\title{
DIAGNOSIS OF HEPATITIS C VIRUS IN BRAZILIAN BLOOD DONORS USING A REVERSE TRANSCRIPTASE NESTED POLYMERASE CHAIN REACTION: COMPARISON WITH ENZYME IMMUNOASSAY AND RECOMBINANT PROTEIN IMMUNOBLOT ASSAY
}

Neiva S. L. GONÇALES(1), Fernando F. COSTA(1,3), José VASSALLO(2) \& Fernando L. GONÇALES JR.(3)

\begin{abstract}
SUMMARY
Screening blood donations for anti-HCV antibodies and alanine aminotransferase (ALT) serum levels generally prevents the transmission of hepatitis $\mathrm{C}$ virus ( $\mathrm{HCV}$ ) by transfusion. The aim of the present study was to evaluate the efficiency of the enzyme immunoassay (EIA) screening policy in identifying potentially infectious blood donors capable to transmit hepatitis C through blood transfusion. We have used a reverse transcriptase (RT)-nested polymerase chain reaction (PCR) to investigate the presence of HCVRNA in blood donors. The prevalence of HCV-RNA positive individuals was compared with the recombinant immunoblot assay (RIBA-2) results in order to assess the usefulness of both tests as confirmatory assays. Both tests results were also compared with the EIA-2 OD/C ratio (optical densities of the samples divided by the cut off value). ALT results were expressed as the ALT quotient (qALT), calculated dividing the ALT value of the samples by the maximum normal value (53UI/l) for the method. Donors ( $\mathrm{n}=178$ ) were divided into five groups according to their EIA anti-HCV status and qALT: group A (EIA $\geq 3$, ALT $<1$ ), group B (EIA $\geq 3$, ALT $>1$ ), group $\mathrm{C}(1 \leq \mathrm{EIA}<3, \mathrm{ALT}<1)$, group $\mathrm{D}(1 \leq \mathrm{EIA}<3, \mathrm{ALT}>1)$ and group $\mathrm{E}(\mathrm{EIA} \leq 0.7)$. HCV sequences were detected by RT-nested PCR, using primers for the most conserved region of viral genome. RIBA-2 was applied to the same samples. In group A ( $\mathrm{n}=6)$, all samples were positive by RT-nested PCR and RIBA-2. Among 124 samples in group B, 120 (96.8\%) were RIBA-2 positive and 4 (3.2\%) were RIBA-2 indeterminate but were seropositive for antigen c22.3. In group B, $109(87.9 \%)$ of the RIBA-2 positive samples were also RTnested PCR positive, as well as were all RIBA-2 indeterminate samples. In group $\mathrm{C}$, all samples $(\mathrm{n}=9)$ were RT-nested PCR negative: $4(44.4 \%)$ were also RIBA-2 negative, 4 (44.4\%) were RIBA-2 positive and 1 (11.1\%) was RIBA-2 indeterminate. HCV-RNA was detected by RT-nested PCR in 3 (37.5\%) out of 8 samples in group D. Only one of them was also RIBA-2 positive, all the others were RIBA-2 indeterminate. All of the group E samples (controls) were RT- nested PCR and RIBA-2 negative. Our study suggests a strong relation between anti-HCV EIA-2 ratio $\geq 3$ and detectable HCV-RNA by RT-nested PCR. We have also noted that blood donors with RIBA-2 indeterminate presented a high degree of detectable HCV-RNA using RT-nested PCR (75\%), especially when the c22.3 band was detected.
\end{abstract}

KEYWORDS: Anti-HCV; Blood donors; Viral hepatitis; Hepatitis C; Brazil, PCR; RIBA.

\section{INTRODUCTION}

Since the cloning and characterization of hepatitis $\mathrm{C}$ virus $(\mathrm{HCV})^{3}$ as the major cause of post-transfusion non-A, non-B hepatitis around the world ${ }^{5,12,20}$, a number of serological tests using recombinant and/or synthetic polypeptides derived from the HCV genome have been developed to detect circulating antibodies. The first-generation anti-HCV enzyme immunoassay (EIA-1) detected only antibodies to the recombinant $\mathrm{HCV}$ antigen $\mathrm{c} 100-3^{12}$. The use of this test to low risk populations such as blood donors resulted in a high number of falsepositive and false-negative results ${ }^{4,9,16}$. The second generation HCV EIA (EIA-2) assay relies on the detection of antibodies against two additional antigens: c33c (in the NS3 region, that codes the putative protease/ helicase) and c22-3 (in the core region) ${ }^{29}$. In the third-generation EIA (EIA-3) peptides from the NS5 region and some recombinant antigens from other regions have been replaced by synthetic peptides ${ }^{25}$. The improvement in sensitivity and specificity from EIA-2 to EIA-3 was not so important as the improvement observed from EIA-1 to EIA-2. The average period for HCV seroconversion after blood transfusion has been shortened with each new generation: 7 to 8 weeks for EIA-3 compared with 10 weeks for EIA-2 and 16 weeks for EIA- $1^{8}$. Incorporating these new antigens improved the sensitivity of the assay but the question of specificity remains open ${ }^{6,8,15}$. Thus, in EIA-positive cases, it is important to confirm these tests results using other assays.

(1) Centro de Hematologia e Hemoterapia, UNICAMP, Campinas, São Paulo, Brasil.

(2) Departamento de Anatomia Patológica da Faculdade de Ciências Médicas, UNICAMP, Campinas, São Paulo, Brasil.

(3) Disciplina de Doenças Transmissíveis da Faculdade de Ciências Médicas, UNICAMP, Campinas, São Paulo, Brasil.

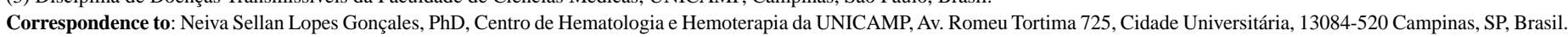
Fone: 55-19-788-8731, Fax: 55-19-289-4513, E-Mail: neiva@unicamp.br 


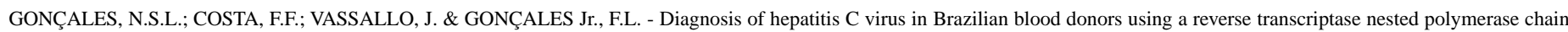
reaction: comparison with enzyme immunoassay and recombinant protein immunoblot assay. Rev. Inst. Med. trop. S. Paulo, 42(5): 263-267, 2000.

A possible supplementary test is the recombinant protein immunoblot assay, also available as a second-generation test (RIBA-2) ${ }^{26}$. In addition to the three recombinant antigens mentioned above, this test also utilizes the recombinant protein 5-1-1 and superoxide dismutase (SOD) ${ }^{27}$. Recently, a more sensitive third-generation of RIBA (RIBA-3) has been introduced and uses the same antigens as the EIA-3. Another approach relies on the detection of HCV-RNA by the RT polymerase chain reaction (PCR) ${ }^{28}$. Using PCR, the presence of HCV-RNA can be confirmed in samples with positive or indeterminate EIA results. Hepatitis $\mathrm{C}$ viremia is known to be present in most patients with chronic hepatitis $\mathrm{C}$, including those with a long-standing infection or advanced liver disease such as cirrhosis or hepatocellular carcinoma ${ }^{10}$. Most $(80 \%-90 \%)$ EIA-2-positive patients with chronic hepatitis $\mathrm{C}$ are RIBA-2 and HCV-RNA positive while approximately $10 \%$ are RIBA indeterminate and $60 \%-70 \%$ of whom will be HCV-RNA positive ${ }^{2,14}$. Contrary to patients with chronic liver disease, only $36 \%$ to $65 \%$, anti-HCV (EIA-2) positive blood donors are RIBA positive and $20 \%$ to $30 \%$ are RIBA indeterminate. The percentage of EIA2-positive blood donors who have detectable HCV-RNA in serum when tested by RT-PCR varies from $70 \%$ to $90 \%$ for those who are RIBA positive to $2 \%$ to $40 \%$ for those who are RIBA indeterminate ${ }^{18,23,24}$.

The aim of the present study was to evaluate the efficiency of the EIA screening policy in identifying potentially infectious blood donors capable to transmit hepatitis $\mathrm{C}$ through blood transfusion at an University Hospital Blood Bank at Campinas, São Paulo, Brazil. We have used a reverse transcriptase (RT)-nested PCR to investigate the presence of HCVRNA in blood donors. The prevalence of HCV-RNA positive individuals was compared with the RIBA- 2 results in order to assess the usefulness of both tests as confirmatory assays and EIA-2 ratio.

\section{MATERIALS AND METHODS}

Blood donors: Hepatitis C-infected blood donors in this study were identified during routine screening for $\mathrm{HCV}$ antibodies after blood donation. In our blood bank, annually around 30,000 units of blood are collected and we have $1.9-2.1 \%$ of positivity for anti-HCV by EIA-2 test. The 178 blood donors selected were classified according to their anti-HCV status and alanine-aminotransferase (ALT) level. One hundred and forty-seven $(82.6 \%)$ were anti-HCV reactive and $31(17.4 \%)$ were anti-HCV negative. All selected blood samples tested were negative for anti-HIV 1/2, anti-HTLV I/II, HBsAg and anti-HBc, as well as for markers for Chagas' disease and syphilis (see Table 1).

Anti-HCV screening: Serum samples were screened using a secondgeneration HCV enzyme immunoassay (HCV EIA, Abbott Laboratories, Diagnostic Division, North Chicago, IL, USA). The tests were performed according to the manufacturer's instructions. The results of anti-HCV EIA-2 test were expressed as the optical densities (OD) of the samples divided by the cut off value $(\mathrm{C})$. The mean of three results obtained when it was retested was used to calculate the EIA ratio OD/C of each reagent or indeterminate samples. So, the ratio $\mathrm{OD} / \mathrm{C} \leq 0.7$ was considered non-reagent and was weakly reagent when the ratio OD/C was $\geq 1$ and $<3$. Samples with ratio OD/C $\geq 3$ were considered highly reagent. Samples with ratio OD/C between 0.7-0.99 were not studied.

Alanine-aminotransferase (ALT) determinations: ALT levels were determined using a commercial kit (SGPT ALT, Abbott) and the normal reference interval were 0-53 UI/l. The results were expressed as the ALT
Table 1

Classification of 178 blood donors according to their EIA-2 results and qALT levels

\begin{tabular}{|c|c|c|c|c|c|c|}
\hline \multirow[b]{3}{*}{ EIA* } & \multicolumn{4}{|c|}{ qALT* $^{*}$} & & \\
\hline & \multicolumn{2}{|c|}{ ALT <1 } & \multicolumn{2}{|c|}{ ALT $>1$} & \multicolumn{2}{|c|}{ TOTAL } \\
\hline & $\mathrm{N}^{\circ}$ & $\%$ & $\mathrm{~N}^{\circ}$ & $\%$ & $\mathrm{~N}^{\circ}$ & $\%$ \\
\hline EIA $\geq 3$ & $6[\mathrm{~A}]$ & $(4.6)$ & $124[\mathrm{~B}]$ & (95.4) & 130 & $(100)$ \\
\hline$\geq 1$ EIA $<3$ & $9[\mathrm{C}]$ & (52.9) & $8[\mathrm{D}]$ & $(47.1)$ & 17 & (100) \\
\hline EIA $<0.7$ & $31[\mathrm{E}]$ & $-(0)$ & $-(0)$ & $-(0)$ & 31 & (100) \\
\hline TOTAL & 46 & $(25.8)$ & 132 & $(74.2)$ & 178 & (100) \\
\hline
\end{tabular}

EIA* $^{*}$ Enzyme immunoassay optical density value/cut off

$\mathrm{qALT}^{*}=$ alanine-aminotransferase values expressed as a ratio of the samples value/upper normal value

$[A],[B],[C],[D],[E]=$ resulting groups of patients.

quotient (qALT), calculated dividing the ALT value of the samples by the maximum normal value for the method. When the ALT level was elevated qALT was always $>1$.

Recombinant protein immunoblot assay: All samples were tested using a second-generation immunoblot assay, RIBA-2 (Ortho Diagnostic Systems, Raritan, NJ, USA). The tests were performed and evaluated as described by the manufacturer. For the RIBA-2, samples reacting with at least two bands were considered positive, whereas samples reacting with only one band were considered indeterminate. Samples with no seroreactivity to any $\mathrm{HCV}$ recombinant antigen were considered RIBA2-negative.

cDNA synthesis: Sera from blood donors were stored at $-20{ }^{\circ} \mathrm{C}$. For the reverse transcription (RT)-PCR amplification of HCV from human serum, we used a simple rapid method that does not require the RNA extraction step ${ }^{21}$. After denaturation $\left(30 \mathrm{~s}\right.$ at $\left.92^{\circ} \mathrm{C}\right), 3 \mu \mathrm{l}$ of serum were added to the RT mixture (50 mM Tris- $\mathrm{HCl}, \mathrm{pH} 8.2,70 \mathrm{mM} \mathrm{KCl}, 10 \mathrm{mM}$ $\mathrm{MgCl}_{2,} 4 \mathrm{mM}$ DTT 12 units of human placental ribonuclease inhibitor (RNAguard, Pharmacia, Uppsala, Sweden), 0.4\% Nonidet P-40, 50 pmoles of a specific antisense primer (R1), $250 \mathrm{mM}$ dNTPs and 6 units of avian myeloblastosis virus reverse transcriptase (AMV-RT, United State Biochemical Corp, Cleveland, $\mathrm{OH}$ ), in a final volume of $25 \mu \mathrm{l}$ ). RT was carried out at $42{ }^{\circ} \mathrm{C}$ for $60 \mathrm{~min}$ and the resulting cDNA was immediately denatured by heating for $5 \mathrm{~min}$ at $100^{\circ} \mathrm{C}$.

Nested PCR assay: Two primer sets were used to amplify the HCV sequences. Each set consisted of two "outer" primers F1 (5' GGCGACACTCCACCATAGATC - 3') and R1 (5'GGTGCACGGTCTACGAGACCT - 3'), which generated a PCR product of $324 \mathrm{bp}$ and two "inner" primers F3 (5'CTGTGAGGAACTACTGTCTTC - 3') and R3 (5'CCCTATCAGGCAGTACCACAA - 3') which generated a PCR product of $256 \mathrm{bp}$ (nested PCR ${ }^{7}$. Both primer sets correspond to sequences in the 5'-non-coding region (NCR) of the $\mathrm{HCV}$ genome.

Five microliters of cDNA were denatured for $5 \mathrm{~min}$ at $94{ }^{\circ} \mathrm{C}$ in $45 \mu \mathrm{l}$ of PCR buffer (20 mM of Tris- $\mathrm{HCl}, \mathrm{pH} 8.4$, containing $50 \mathrm{mM} \mathrm{KCl}$ and 
$2 \mathrm{mM} \mathrm{MgCl}$ ) together with 100 pmol of both "outer" primers and 200 $\mathrm{mM}$ of each dNTP. This reaction mixture was covered with $100 \mu \mathrm{l}$ of mineral oil. Following the denaturation step, 2.5 units Thermus aquaticus DNA polymerase (Bethesda Research Laboratories, Life Technologies Inc., Gaithersburg, Maryland) were added, and the samples were submitted to 35 cycles of amplification as follows: $1 \mathrm{~min}$ at $94{ }^{\circ} \mathrm{C}, 1 \mathrm{~min}$ at $55^{\circ} \mathrm{C}$ and $1 \mathrm{~min}$ at $72{ }^{\circ} \mathrm{C}$ in a DNA Thermal Cycler (Perkin Elmer Cetus, Foster City, CA, USA). Five microliters of the newly amplified material were then submitted to a second round of amplification using the "inner" primers. Following denaturation, 30 cycles of amplification were performed with each cycle consisting of $1 \mathrm{~min}$ at $94{ }^{\circ} \mathrm{C}, 1 \mathrm{~min}$ at $55^{\circ} \mathrm{C}$ and $1 \mathrm{~min}$ at $72{ }^{\circ} \mathrm{C}$. A final step $\left(7 \mathrm{~min}\right.$ at $\left.72{ }^{\circ} \mathrm{C}\right)$ was included after the last cycle of both the first and second rounds of amplification. For each PCR assay, water was used as a negative control and serum from one individual HCV positive by EIA and confirmed by RT-PCR and liver biopsy was used as a positive control. Carryover contamination was prevented as described by KWOK \& $\mathrm{HIGUCHI}^{13}$. The final amplification product was mixed with bromphenol blue, electrophoresed in a $2 \%$ agarose gel, stained with ethidium bromide, visualized and photographed as previously described ${ }^{28}$. Samples were considered positive if they yielded at least two positive results from three amplifications. Negative samples showed two negative results from two different reactions.

Statistical analysis: The $\chi^{2}$ test and Fisher exact test correction were used to analyze the data.

\section{RESULTS}

The samples were classified according to their EIA ratio and qALT (Table1). The RT-nested PCR and RIBA-2 results for these samples were described below (see Table 2).

Group A ( $n=6)$ : All 6 cases with EIA ratio $\geq 3$ and qALT $<1$ were RT-nested PCR and RIBA-2 positive.

Group B ( $\mathrm{n}=124)$ : In this group with EIA ratio $\geq 3$ and $\mathrm{qALT}>1$, $120(96.8 \%)$ were RIBA-2 positive and $4(3.2 \%)$ were RIBA-2 indeterminate with seropositivity only to antigen c22.3. One hundred and nine $(87.9 \%)$ samples were both RT-nested PCR and RIBA-2 positive and all RIBA-2 indeterminate samples were RT-nested PCR positive.
Group C (n=9): All the samples with EIA ratio $\geq 1$ and $<3$ and qALT $<1$ were RT-nested PCR negative. Concerning RIBA-2 results, 4 $(44.4 \%)$ samples were negative, $4(44.4 \%)$ were positive and one was indeterminate.

Group D ( $\mathrm{n}=8)$ : In this group, with EIA ratio $\geq 1$ and $<3$ and qALT $>1$, the RT-nested PCR detected three positive samples (37.5\%), only one of them was also RIBA-2 positive.

Group E ( $\mathrm{n}=31)$ : In this group (controls), with EIA ratio $\leq 0.7$ and qALT $<1$, all of the samples were RT-nested PCR and RIBA-2 negative.

Relationship between RIBA-2 indeterminate and RT- nested PCR results: Eight out of 178 sera $(4.5 \%)$ were indeterminate by the RIBA2. Among these samples, 6 (75\%) were positive by RT-nested PCR. Seven out of 8 RIBA-2 indeterminate cases were due to seropositivity to c22.3 and one case to seropositivity to $\mathrm{c} 33 \mathrm{c}$. The six RT-nested PCR positive cases were also positive for c22.3 antigen.

Assessment of divergent results in RT-nested PCR and RIBA-2: Divergent results were considered when a negative result was obtained with one assay, while a positive or indeterminate result was obtained with the other. Twenty-one (11.8\%) divergent results were obtained using RT-nested PCR and RIBA-2. In two of these, the RIBA-2 result was indeterminate, while this result was positive, in the other 19 cases, in spite of the a negative RT-nested PCR result.

\section{DISCUSSION}

The current strategy in Brazil for the prevention of transfusionassociated hepatitis $\mathrm{C}$ relies on the screening of blood donations for anti-HCV and determination of ALT levels. To prevent HCV transmission, all blood donations positive for HCV antibody and/or elevated (>53U/l) ALT levels are discarded. Second generation EIA test for HCV antibody yields greater specificity and sensitivity. However, McHUTCHISON et al. ${ }^{15}$ found little improvement in specificity when testing a low-risk population, although a correlation between optical density values and the presence of HCV RNA was observed.

Supplementary tests such as the recombinant protein immunoblot assay (RIBA-2) or RT-nested PCR can be applied to EIA-2 reactive

Table 2

Results of the RT-nested PCR and RIBA-2 assays in the five groups of donors

\begin{tabular}{|c|c|c|c|c|c|c|}
\hline \multirow[t]{2}{*}{ Group } & \multicolumn{2}{|c|}{ RT-nested PCR ${ }^{a}$} & \multicolumn{2}{|c|}{ RIBA-2 } & \multirow[b]{2}{*}{ Ind $^{\mathrm{b}}$} & \multirow[t]{2}{*}{ RIBA+/PCR+ } \\
\hline & $(+)$ & $(-)$ & $(+)$ & $(-)$ & & \\
\hline$A(n=6) \%$ & $6(100)$ & $-(0)$ & $6(100)$ & $-(0)$ & $-(0)$ & $6(100)$ \\
\hline $\mathrm{B}(\mathrm{n}=124) \%$ & $113(91.1)$ & $11(8.9)$ & $120(96.8)$ & $-(0)$ & $4^{c}(3.2)$ & 109 (87.9) \\
\hline $\mathrm{C}(\mathrm{n}=9) \%$ & $-(0)$ & $9(100)$ & $4(44.4)$ & $4(44.4)$ & $1(11.2)$ & $-(0)$ \\
\hline$D(n=8) \%$ & $3(37.5)$ & $5(62.5)$ & $5(62.5)$ & $-(0)$ & $3^{\mathrm{d}}(37.5)$ & $1(12.5)$ \\
\hline$E(n=31) \%$ & $-(0)$ & $31(100)$ & $-(0)$ & $31(100)$ & $-(0)$ & $-(0)$ \\
\hline Total & 122 & 56 & 135 & 35 & 8 & 116 \\
\hline
\end{tabular}

$\mathrm{a}=$ includes samples with at least one positive result in the RT-nested PCR assay (HCV-RNA positive)

$\mathrm{b}=\mathrm{RIBA}-2$ indeterminate

$\mathrm{c}=\mathrm{RIBA}-2$ indeterminate were positive by RT-nested PCR

$\mathrm{d}=$ two of these RIBA-2 were positive by RT-nested PCR 


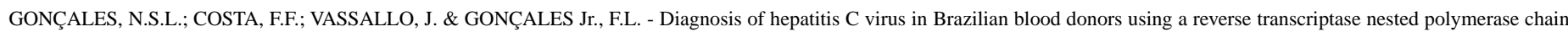
reaction: comparison with enzyme immunoassay and recombinant protein immunoblot assay. Rev. Inst. Med. trop. S. Paulo, 42(5): 263-267, 2000.

samples, thereby improving the reliability of the $\mathrm{HCV}$ diagnosis ${ }^{1}$. We applied both of these tests to 178 sera, classified according to their EIA2 ratio and qALT level. The detection of HCV-RNA by PCR was considered the standard marker for infectivity.

To limit the occurrence of false-negatives in the RT-nested PCR assay, we used primers in the 5'-noncoding region of the HCV genome, which is over $98 \%$ conserved among different isolates ${ }^{17}$.

In our study, we observed a very good relation between the RTnested PCR and RIBA-2 results in group B (Table 2), with no significant difference between the two tests ( $p>0.05$ ). In $87.9 \%$ of HCV-RNApositive donations, the presence of anti-HCV was also confirmed by RIBA-2. This proportion is greater than the $36 \%$ of RIBA-2 positive cases reported in similar individuals in studies conducted in Italy ${ }^{18,22}$ and France $^{24}$ and $39 \%$ observed in USA ${ }^{11}$. In Spain, 33-63\% of anti-HCV positive was also RIBA-2 positive ${ }^{19,23}$. The discrepancy between our results and these cited above may be related to the type of donor included in our evaluation (EIA>3 and qALT>1). In 11 (8.9\%) samples, the reactivity in RIBA contrasted with no reactivity by RT-nested PCR. The question of whether RIBA-2-positive/HCV-RNA-negative results reflect low levels of viremia, loss of infectivity, or failure of the RT-nested PCR assay can be answered only after those donors have been followed and other samples from them could be tested.

The RIBA-2 indeterminate results were generally associated with the presence of HCV-RNA in peripheral blood. The high rate of RIBA2 indeterminate with positive RT-nested PCR results was correlated with the presence of antigen c22.3 in all cases. For this reason, we considered as obligatory to screen RIBA indeterminate donors for HCV-RNA.

ALT screening in conjunction with anti-HCV EIA ratio proved to be valuable in identifying potentially infectious donors capable of transmitting hepatitis $\mathrm{C}$ mainly in donors with EIA-2 ratio $\geq 3$. We observed that donors with anti-HCV ratio $\geq 3$ and qALT $<1$ (group A) were HCV-RNA positive. The high anti-HCV EIA-2 ratio $(\geq 3)$, was also associated with a positive RT-nested PCR result among donors in group B (113/124-91\%). RT-nested PCR was positive in 119/130 (91.5\%) donors with EIA-2 ratio $\geq 3$ (groups A and B), while only 3/17 (17.6\%) were HCV-RNA positive among donors with EIA-2 ratio $\geq 1$ and $<3$ (groups $\mathrm{C}$ and $\mathrm{D}$ ). These data show that elevated EIA-2 ratio $\geq 3$ is associated to RT-nested PCR positivity in anti-HCV positive patients.

A substantially higher rate of viremia as well as anti-HCV positivity confirmed by RIBA-2 was observed for donors in group B compared to group D (87.9\% vs $12.5 \%$ - $\mathrm{p}<0.05)$. The RIBA-2 can exclude false EIA2 reactivities and identify positives fairly well, as judged from the PCR analysis of group D. For the moment, the RIBA-2 should be regarded as confirmatory for anti-HCV EIA-2 reactivity. Although there was a rather strong association between RIBA-2 and RT-nested PCR, some infectious donors will not be detected by the RIBA-2 assay. On the other hand, the RT-nested PCR is very sensitive and specific in detecting viremia and, hence, potentially infectious donors.

Our study suggested a strong correlation between anti-HCV EIA-2 ratio $\geq 3$ and HCV-RNA positivity by PCR. We have also noted that blood donors with RIBA-2 indeterminate presented high degree of positivity in PCR $(75 \%)$ mainly when they had positivity in the $\mathrm{c} 22.3$ band.

\section{RESUMO}

\author{
Diagnóstico da hepatite por vírus $\mathrm{C}$ em doadores de sangue \\ brasileiros, usando a reação de transcrição reversa e a reação em \\ cadeia da polimerase "nested": comparação com os ensaios \\ imunoenzimáticos e imunoblot recombinante
}

Na prevenção da transmissão de Hepatite por Vírus C (HCV) em transfusões de hemocomponentes, utiliza-se rotineiramente, como testes de triagem de doadores de sangue, ensaios que detectam anticorpos antiHCV e dosagens da enzima alanina-aminotransferase (ALT). O presente estudo tem como objetivo principal avaliar a eficiência do ensaio imunoenzimático de segunda geração (EIA-2) como teste de triagem, na identificação de doadores de sangue potencialmente infectados, e portanto, capazes de transmitir hepatite $\mathrm{C}$ pelos hemocomponentes. Nós utilizamos o ensaio de transcrição reversa (RT) e a reação em cadeia da polimerase "nested" («nested PCR») para investigar a presença do RNA do vírus da hepatite $\mathrm{C}(\mathrm{HCV})$ em doadores de sangue. A prevalência do RNA-HCV em indivíduos positivos foi comparada com os resultados do ensaio complementar imunoblot recombinante de segunda geração (RIBA-2) com o intuito de avaliar a utilidade de ambos como testes confirmatórios. Estes dois testes também foram comparados com a razão DO/C (valores de densidade óptica das amostras dividida pelo valor de corte da reação) no EIA-2. Os resultados das dosagens da ALT foram expressos como uma razão unitária denominada qALT, que representa o cálculo do valor do ALT da amostra dividido pelo valor máximo considerado normal para o teste (53UI/L). Os doadores de sangue foram divididos em cinco grupos de acordo com os resultados do EIA-2 e o qALT: grupo A (EIA $\geq 3, A L T<1)$, grupo $B(E I A \geq 3, A L T>1)$, grupo $C$ $(1 \leq \mathrm{EIA}<3, \mathrm{ALT}<1)$, grupo $\mathrm{D}(1 \leq \mathrm{EIA}<3, \mathrm{ALT}>1)$ e grupo $\mathrm{E}(\mathrm{EIA} \leq 0,7)$. As sequiências do HCV foram detectadas por RT-nested PCR, utilizandose os "primers" da região mais conservada do genoma viral. O teste RIBA-2 foi aplicado nas mesmas amostras. No grupo A $(n=6)$ todas as amostras foram positivas para o RT-nested PCR e RIBA-2. Entre as 124 amostras do grupo B, $120(96,8 \%)$ eram RIBA-2 positivas e $4(3,2 \%)$ eram RIBA-2 indeterminadas mas positivas para o antígeno c22.3. No grupo B, as 109 amostras $(87,9 \%)$ RIBA-2 positivas também apresentaram RT-nested PCR positivas, bem como todas as amostras com RIBA-2 indeterminadas. No grupo $C$, todas as amostras $(n=9)$ foram RT-nested PCR negativas: $4(44,4 \%)$ apresentaram também RIBA-2 negativa enquanto que $4(44,4 \%)$ foram RIBA-2 positivas e $1(11,1 \%)$ foi RIBA-2 indeterminada. O RNA-VHC foi detectado por RT-nested PCR em $3(37,5 \%)$ das 8 amostras do grupo D. Todas as amostras do grupo E (controle) foram RT-nested PCR e RIBA-2 negativas. Nosso estudo sugere uma forte relação entre a razão anti-HCV EIA-2 $\geq 3$ e a positividade do RNA-HCV por RT-nested PCR. Nós também pudemos observar que os doadores de sangue com RIBA-2 indeterminados apresentaram um alto grau de positividade no RT-nested PCR (75\%), especialmente quando está presente a banda correspondente ao antígeno c22.3.

\section{ACKNOWLEDGEMENTS}

The authors express their gratitude to those who participated in the study, including the Viral Hepatitis Study Group for their help in the clinical trial and Dr Stephen Hyslop for editorial assistance. This study was supported in part by Fundo de Apoio ao Ensino e Pesquisa (UNICAMP). 


\section{REFERENCES}

1. CARDOSO, M.S.; JOCHIM, H.; HESSE, R. et al - Evaluating recombinant protein immunoblot assay and polymerase chain reaction for diagnosis of non-A, non-B hepatitis. J. infect. Dis., 166: 450-451, 1992.

2. CHEMEllo, L.; CAVAlLETO, D.; PONTISSO, P. et al - Patterns of antibodies to hepatitis $\mathrm{C}$ virus in patients with chronic non- $\mathrm{A}$, non-B hepatitis and their relationship to viral replication and liver disease. Hepatology, 17: 179-182, 1993.

3. CHOO, Q.-L.; WEINER, A.J.; OVERBY, L.R. et al - Hepatitis C virus: the major causative agent of viral non-A, non-B hepatitis. Brit. med. Bull., 46: 423-441, 1990.

4. COUROUCÉ, A.M.; JANOT, C. \& THE HEPATITIS STUDY GROUP OF THE FRENCH SOCIETY OF BLOOD TRANSFUSION - Recombinant immunoblot assay first and second generations on 732 blood donors reactive for antibodies to hepatitis $\mathrm{C}$ virus by ELISA. Vox Sang. (Basel), 1: 177-180, 1991.

5. ESTEBAN, J.I.; ESTEBAN, R.; VILADOMIU, L. et al. - Hepatitis C virus antibodies among risk groups in Spain. Lancet, 2: 294-297,1989.

6. FRÖSNER, G.G. - Sensitivity of second-generation anti-HCV test for diagnosis of acute hepatitis C. Infection, 19: 434, 1991.

7. GARSON, J.A.; TEDDER, R.S.; BRIGGS, M. et al. - Detection of hepatitis C viral sequences in blood donations by "nested" polymerase chain reaction and prediction of infectivity. Lancet, 335: 1419-1422, 1990.

8. GRETCH, D.R. - Diagnostic tests for hepatitis C. Hepatology, 26(suppl.1): 43S-47S, 1997.

9. HAYASHI, J.; NAKASHIMA, K.; KISHIHARA, Y. et al - Improved detection of antibodies to hepatitis $C$ virus by second generation assay in patients with chronic non-A, non-B liver disease. J. infect. Dis., 26: 287-294, 1993.

10. HORIIKE, N.; NONAKA, T.; KUMAMOTO, I. et al. - Hepatitis C virus plus-and minus strand RNA in hepatocellular carcinoma and adjoining nontumorous liver. J. med. Virol., 41: 312-315, 1993.

11. KLEINMAM, S.; ALTER, H.; BUSCH, M. et al. - Increased detection of hepatitis C virus $(\mathrm{HCV})$-infected blood donors by multiple-antigen $\mathrm{HCV}$ enzyme immunoassay. Transfusion, 32: 805-813, 1992.

12. KUO, G.; CHOO, Q.-L.; ALTER, H.J. et al. - An assay for circulating antibodies to a major etiologic virus of human non-A, non-B hepatitis. Science, 244: 362-364, 1989.

13. KWOK, S \& HIGUCHI, R. - Avoiding false positives with PCR. Nature (Lond.), 339: 237-238, 1989.

14. LOK, A.S.F. \& GUNARATNAM, N.T. - Diagnosis of hepatitis C. Hepatology, 26(suppl. 1): 48S-56S, 1997.

15. McHUTCHISON, J.G.; PERSON, J.L.; GOVINDARAJAN, S. et al. - Improved detection of hepatitis C virus antibodies in high-risk populations. Hepatology, 15: 19-25, 1992.
16. NICHOLSON, S.; LESLIE, D.E.; EFANDIS, T. et al. - Hepatitis C antibody testing: problems associated with non-specific binding. J. virol. Meth., 33: 311-317, 1991.

17. OKAMOTO, H.; OKADA, S.; SUGIYAMA, Y. et al. - The 5'-terminal sequence of the hepatitis C virus genome. Jap. J. exp. Med., 60: 167-177, 1990

18. PRATI, D.; CAPELLI, C.; ZANELLA, A. et al. - Influence of different hepatitis C virus genotypes on the course of asymptomatic hepatitis $\mathrm{C}$ virus infection. Gastroenterology, 110: 178-183, 1996

19. PRIETO, M.; OLASO, V.; VERDU, C. et al. - Does the healthy hepatitis C virus carrier state really exist? An analysis using polymerase chain reaction. Hepatology, 22: 413-417, 1995.

20. PRINCE, A.M.; BROTMAN, B.; INCHAUSPE, G. et al. - Patterns and prevalence of hepatitis $\mathrm{C}$ virus infection in posttransfusion non-A, non-B hepatitis. J. infect.Dis., 167: 1296-1301, 1993.

21. RAVAGGI, A.; PRIMI, D. \& CARIANI, E. - Direct PCR amplification of HCV RNA from human serum. PCR Meth. Applic., 1: 291-292, 1992.

22. ROSSINI, A.; GAZZOLA, G.B.; RAVAGGI, A. et al. - Long-term follow-up and infectivity in blood donors with hepatitis $\mathrm{C}$ antibodies and persistently normal alanine aminotransferase levels. Transfusion, 35: 108-111, 1995.

23. SALMERON, F.J.; PALACIOS, A.; PEREZ-RUIZ, M. et al. - Epidemiology, serological markers, and hepatic disease of anti-HCV ELISA-2 positive blood donors. Dig. Dis. Sci., 41: 1933-1938, 1996

24. SERFATY, L.; NOUSBAUM, J.B.; ELGHOUZZI, M.H. et al. - Prevalence, severity, and risk factors of liver disease in blood donors positive in a second-generation antihepatitis C virus screening test. Hepatology, 21: 725-729, 1995.

25. SCHIFF, E.R.; MEDINA, M. \& KAHN, R.S. - New perspectives in the diagnosis of hepatitis C. Semin. Liver Dis., 19(suppl. 1): 3-15, 1999.

26. VAN DER POEL, C.L.; CUYPERS, H.T.M.; REESINK, H.W. et al. - Confirmation of hepatitis $\mathrm{C}$ virus infection by new four-antigen recombinant immunoblot assay. Lancet, 337: 317-319, 1991.

27. WIDELL, A.; MANSSON, A.-S.; SUNDSTRÖM, G. et al. - Hepatitis C virus-RNA in blood donors sera detected by the polymerase chain reaction: comparison with supplementary hepatitis C antibody assays. J. med. Virol., 35: 253-258, 1991.

28. WILLEMS, M.; PEERLINCK, K.; MOSHAGE, H. et al. - Hepatis C virus-RNAs in plasma and in peripheral blood mononuclear cells of hemophiliacs with chronic hepatitis C: evidence for viral replication in peripheral blood mononuclear cells. J. med. Virol., 42: 272-278, 1994.

29. YOUNOSSI, Z. \& McHUTCHISON, J. - Serological tests for HCV infection. Viral Hepatitis Rev., 2: 161-173, 1996.

Received: 29 March 2000

Accepted: 26 June 2000 